\title{
河床における岩盤上の流砂の集中度合に関する 実験的検討と数值シミュレーション \\ AN EXPERIMENTAL STUDY AND NUMERICAL SIMULATION ABOUT DEGREE OF BEDLOAD CONCENTRATION ON BEDROCK
}

\author{
及川 森 1 - 岩崎 理樹 $2 \cdot$ 山口 里実 $3 \cdot$ 清水 康行 4 ・井上 卓也 5 \\ Shin OIKAWA, Toshiki IWASAKI, Satomi YAMAGUCHI, Yasuyuki SHIMIZU, Takuya INOUE
1学生会員 北海道大学大学院工学院環境フィールド工学専攻（０60-0813 札幌市北区北13条西8丁目） 2学生会員 工修 北海道大学大学院工学院（テ060-0813 札幌市北区北13条西8丁目) 3 正会員 工博 北海道大学工学研究院准教授（豆060-0813 札幌市北区北13条西8丁目） 4正会員 工博 北海道大学工学研究院教授（干060-0813 札幌市北区北13条西8丁目） 5 正会員工修 (株開発工営社（干060-0004 札幌市中央区北4条西5丁目1番地）

\begin{abstract}
This paper presents the fundamental studies on the bed degradation process of bedrock induced by the bedload transport over the bedrock. We performed the laboratory experiments focusing on the dependency of the grain size and the strength of bedrock for the erosion velocity of bedrocks. The experimental results show that the grain size and strength of bedrock can affect to the erosion velocity equation of bedrocks. In addition, the movement of the sediment particles over bedrock which has constant side inclining bed was measured to understand the direction of sediment over the bed. We also carried out the numerical simulation of bedrock erosion process by the sediment transport over bedrock to understand the performance of the model proposed by us. The comparison between laboratory experiment and numerical simulation shows that the proposed model overestimates the effect of local slope for sediment transport direction over the bedrocks.
\end{abstract}

Key Words : bedrock degradation, bedload, slurry-erosion, The Ishikari River, The Toyohira River

\section{1.はじめに}

\section{1 背景と目的}

岩床河川では，河床における岩の露出が原因で, 局所的に急激な洗掘が生じることが示唆されている. 石狩川上流部や豊平川花魁淵付近(写真-1)でも，河 床を覆っていた砂礫が一掃され，岩盤が露出してい る区間が増加しており，河川管理面からも岩盤河床 の著しい洗掘を予測することは重要な課題の一つで あり，近年注目されてきている。

筆者による既往の研究 ${ }^{1)}$ (以下”及川ら ${ }^{1)}$ ” と表す)で は, 現地実験の代替, 補助となる室内実験手法を提 案し, 室内実験スケールで岩盤の侵食速度式の推定 を行い, 岩の摩耗も考慮した河床変動計算モデルを 開発した。特に現地実験水路の再現計算では, 現地 実験水路 ${ }^{2)}$ に酷似した岩盤上の澪筋パターンが確認 され，モデルによってある程度岩盤侵食過程を再現 できることが確かめられた。流砂が充分に存在しな いような岩盤上の流砂量に関しては，竹林らの掃流 層モデル ${ }^{3)}$ を用いた手法で補正を行った。

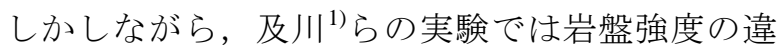
いや岩盤上を流れる砂砶の粒径の違いによって侵食 速度がどのように異なるのかを示していない。また， 河床変動計算では, 岩盤上の流砂量として砂礫河床 を想定して導出された平衡流砂量式を用いているた め, 岩盤上の流砂運動を適切に推定しているか定か
ではない，岩盤の侵食量は岩盤上の流砂量に大きく 依存するため, 流れに対する横断方向への流砂の集 中度合を把握することは重要な課題の一つである。

そこで，本文では，実河川の岩盤侵食を予測する ために，侵食量の岩盤強度依存及び粒径依存に関す る実験を行い, 岩盤の侵食速度式の再考察を行う。 また，岩盤上の流砂の挙動に関する実験を行い，流 砂運動と侵食量の関係を調べ, 従来の数值シミュ レーションと比較し, 澪筋部の深掘れにどの程度流 砂運動が寄与しているか考察する.

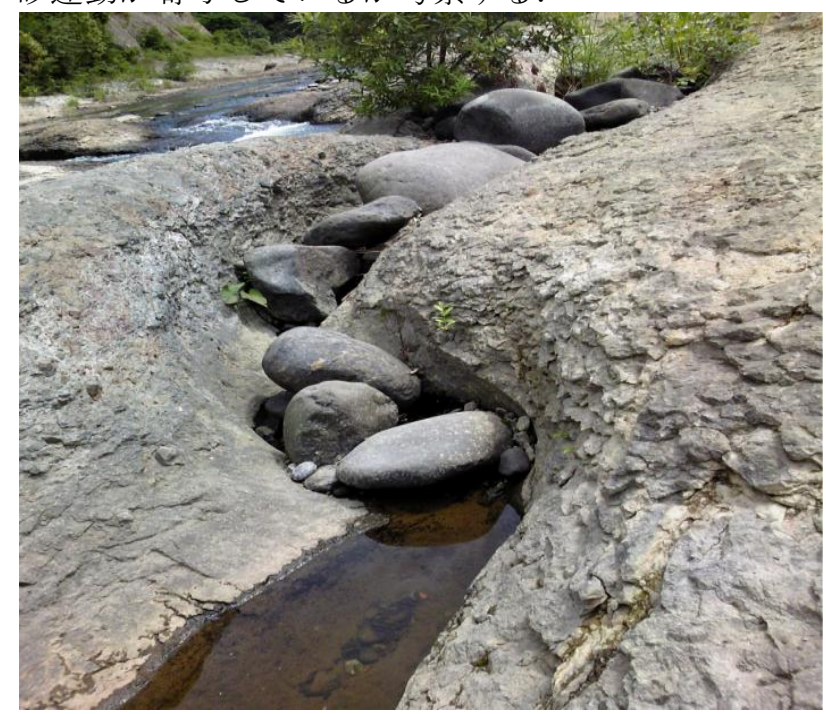

写真-1＼cjkstart豊平川花魁淵の澪筋と堆積した碟 


\section{2 研究手法}

まず，侵食量の岩盤強度依存及び粒径依存を確認 するために, 及川ら ${ }^{1)}$ の実験に倣って, 回転水槽と 石膏を用いて実験を行った。岩盤強度依存性は，異 なる強度を持つ石狩川上流部と豊平川花魁㳢の河床 岩質を石膏で再現し，それぞれの侵食速度を比較す ることで確認した。なお今回，岩質の違いは，予め 一軸針貫入強度と水石亳比都の関係を調べ，井上ら による実河川の河床岩盤の一軸圧縮強度データ4)を 用いることで再現した。一方, 粒径依存性は, 給砂 する砂礫粒径に $5 \mathrm{~mm}$ と $10 \mathrm{~mm}$ の 2 パターン用い，それ ぞれの侵食速度を比較することで確認した。

次に，横断方向にも勾配をつけた直線水路を用い て, 岩盤上の砂磁の動きを縦方向と横方向に分けて 画像解析を行い, 縦断方向掃流砂量と横断方向掃流 砂量の比を調べた。その際同時に洗掘量を測定した。

最後に, 及川ら ${ }^{1)}$ が提案したモデルに上述の流砂 量比を反映させて数値計算を行い, 洗掘量や流砂の 集中度をそれぞれ室内実験と比較し考察した。

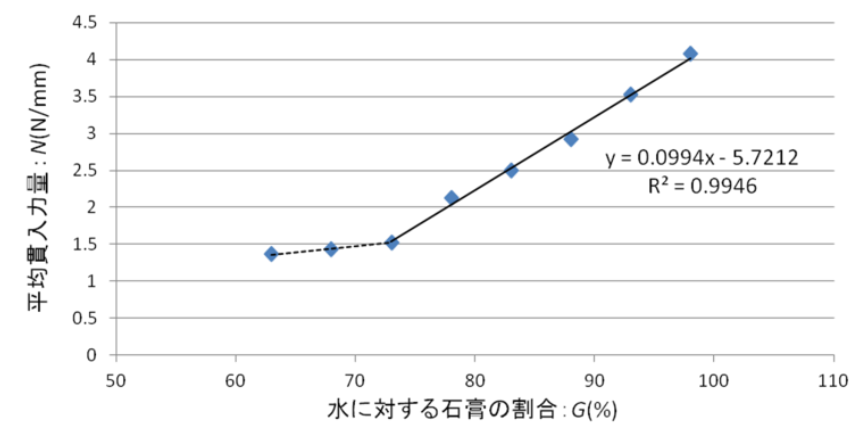

図-1＼cjkstart平均貫入力量と水石膏比の関係

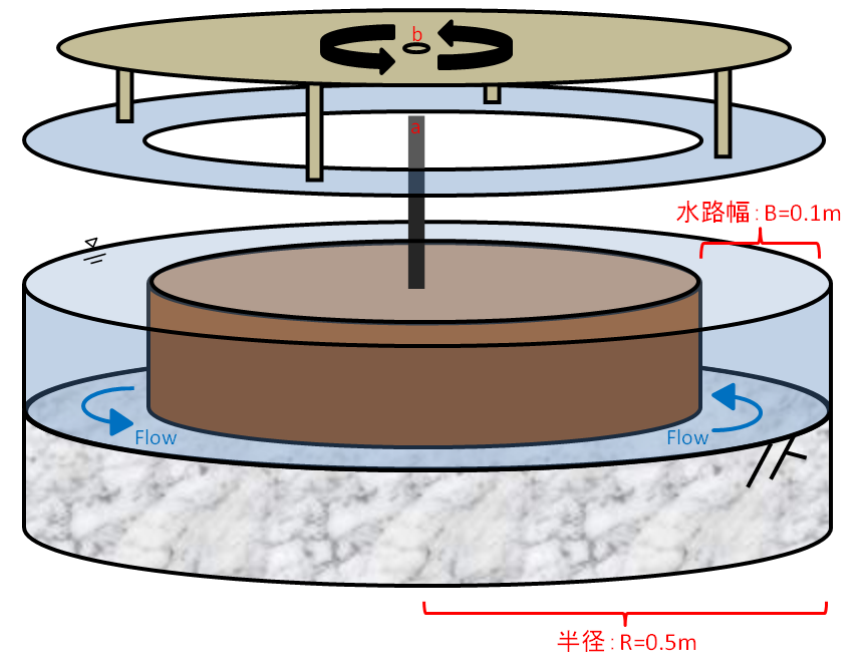

図-2 回転水槽模式図(上:天板, 下:水槽)

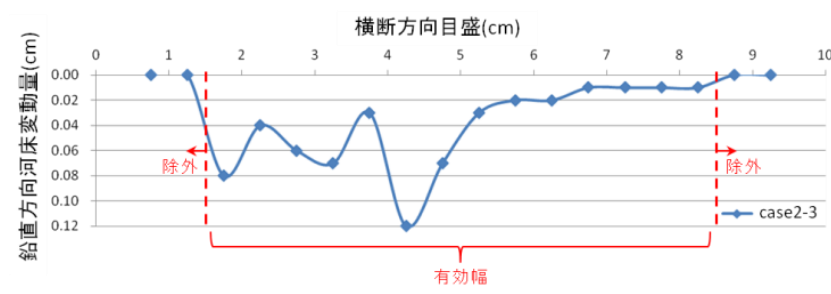

図-3＼cjkstart有効幅を示す河床変動量図(case2-3)

\section{2. 侵食量の粒径依存及び岩盤強度依存に関 する実験}

\section{1 一軸針貫入強度試験}

実験水路の河床は，現地にある岩の代わりに石膏 を用いている. 石膏の水和反応によって硬化する性 質を利用しており，水と石膏の重量率を変えること で，その強度をある程度変化させることができる。

水石亳比 $G$ を変えた8個の供試体に対して針貫入試 験 ${ }^{4)}$ を複数回行い, 平均貫入力量 $N(\mathrm{~N} / \mathrm{mm})$ をそれぞ れプロットしたものを図-1に示す。これより $G=73 \%$ 以上の割合で水に石膏を溶かした場合， $N$ と $G$ の間 に(1)式のような関係を得た。 また，水石膏比を大き くするとワーカビリティが著しく低下することから， $G \geqq 100 \%$ では連続的な貫入試験は行なわなかった.

$$
N=0.0994 G-5.7212
$$

また，一軸圧縮強度 $f$ との関係は(2)式で表される ことが知られている ${ }^{4)}$.

$$
\log _{10} f=0.978 \log _{10} N+2.621
$$

一方, 現地河川の岩盤の実測值 $N$ は, 石狩川上流 部で $N_{I}=2.3(\mathrm{~N} / \mathrm{mm})$, 豊平川花魁淵で $N_{T}=24.2(\mathrm{~N} / \mathrm{mm})$ であり, 式(1)から逆算すればそれぞれ $G_{I}=80.7 \%$, $G_{T}=301.0 \%$ の割合で石膏を溶かせばよいと考えられ る. 実際に養生した石膏河床で針貫入試験を行えば, それらの平均貫入力量はそれぞれ $N_{I}=2.2 \sim 2.4, N_{T}=24$ 〜25(N/mm) となり, 実河川における $N$ 実測值をよく 再現した. 従って, (1)式から推定した水石膏比 $G$ は 妥当であると判断し，このとき式(2)よりそれぞれ $f_{l}=944\left(\mathrm{kN} / \mathrm{m}^{2}\right), f_{T}=9427\left(\mathrm{kN} / \mathrm{m}^{2}\right)$ であることが分かる. このようにして石膏河床を定量的に扱った.

\section{2 実験概要}

岩盤の侵食速度式を得るために，図-2のような実 験装置を用いて, 流速 $V$ と流砂量 $q_{b}$ を与え, 石膏河 床の侵食速度 $D$ を測定する実験を行った。実験装置 は，中央の動力を伝える回転棒(図-2中a)を天板の穴 (図-2中b)に挿入することで, 水面に密着したアクリ ル板が回り, 摩擦力によって水流を発生させる仕組 みになっている。また，河床は水平である.

実験条件について, 河床岩質及び投入砂の粒径を case1(石狩川上流部, $5 \mathrm{~mm}$ ), case2(石狩川上流部, $10 \mathrm{~mm}$ ), case3(豊平川花魁淵， $5 \mathrm{~mm}$ ) と設定して実験 を行い，流下方向に対して垂直な断面を測線として 洗掘量を測定した. 流砂量及び平均流速の測定法に 関しては，及川ら ${ }^{1)} の$ 実験と同様の方法を用いた。 また図中の測線を「CS」と表す。

また実験中に, 内岸側で堆積が起きたり, 外岸側 で流砂が通過しなかったりするような点は, 実験後 も洗掘は見られない。このような点を除外した水路 の幅を有效幅(図-3) とし, 有効幅の範囲内で流砂量 や侵食速度の算出を行った．これを考慮することに よって, case毎の特徵が大きく顕在化する. 後述す る及川ら ${ }^{1)} の$ 実験データにも同様の操作を施すこと で，両者の比較ができるようになっている. 
表-1＼cjkstart回転水槽実験の全条件とその結果

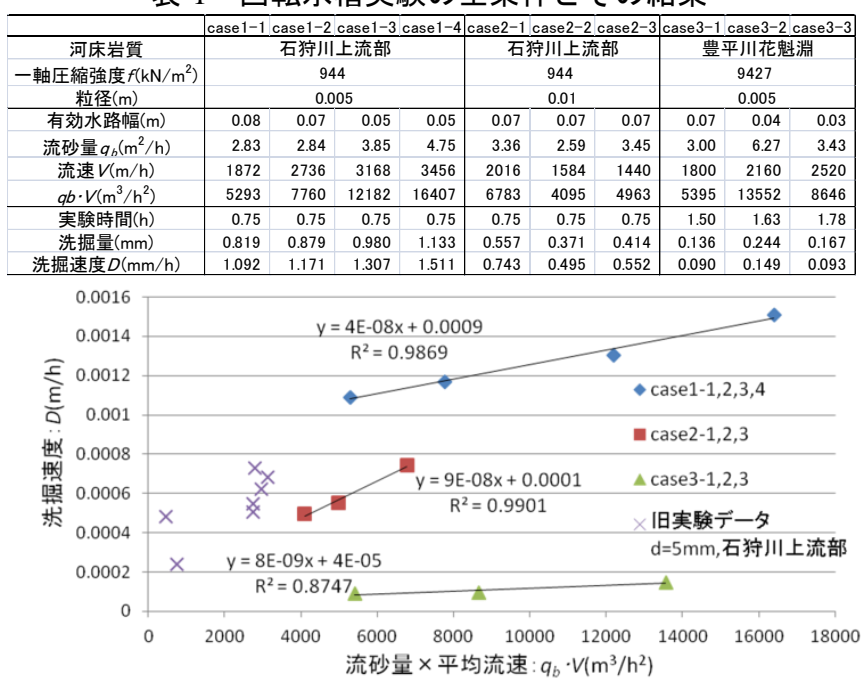

図-4 case $1,2,3$ 毎の $q_{b} \cdot V-D$ 図

\section{3 実験結果と考察}

実験条件及び実験結果を表-1に示す。また，これ らのデータから横軸に $q_{b}$ とVの積, 縦軸に $D$ を case毎 にプロットしたものを図-4に示す.

case1 と case2を比較したとき，粒径を大きくすれ ば侵食速度式の傾きは大きくなることが分かる。こ

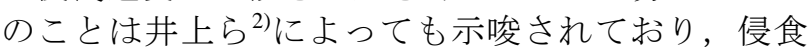
速度式の粒径依存性が窥える。今回の実験の範囲で は，粒径の大きいcaseで侵食速度が小さくなってい る. 図-4の侵食速度の傾きが一定值をとれば $q_{b} \cdot V か ゙$ 大きい領域では，逆に粒径の大きいcaseで侵食速度

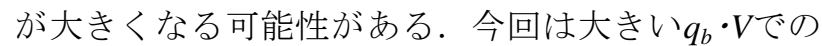
実験を試みたが，これを明らかにするためには $q_{b} \cdot V$ がさらに大きい領域での実験が今後の課題である.

一方，case1 と case3を比較したとき，岩盤強度を 大きくすれば侵食速度式の傾きは小さくなり全体的 に掘れにくくなることが分かる。ただし， case3では 他caseよりも侵食速度のオーダーが小さく, 今回の 測定方法では侵食速度の差は測定誤差である可能性 が否めないため，侵食速度式の傾きについては検討 の余地を残す．今後はより精度の高い計測機器を用 いるか実験時間より長くとる必要があると考える.

及川ら ${ }^{1)}$ の実験では石狩川上流部を再現する石膏 として $G=78 \%$ のもを採用して実験を行い，粒径 $5 \mathrm{~mm}$ の実験結果は式(3)のような侵食速度式となった。

$$
D=1.0 \times 10^{-7} q_{b} \cdot V+0.0003
$$

一方，今回のcase1で使用している $G_{I}=80.7 \%$ の石亳 の方が幾分か固くなっており，同じく粒径 $5 \mathrm{~mm} の$ case1の結果は式(4)のような侵食速度式となった.

$$
D=4.0 \times 10^{-8} q_{b} \cdot V+0.0009
$$

式(3)と式(4)を考察すれば，式(4)の方が全体の侵食 速度が大きいのに対して，式(3)の方が傾きが大きい さらに，及川ら ${ }^{1)}$ の実験による横軸の定義域は $q_{b}$. $V=300 \sim 2300\left(\mathrm{~m}^{3} / \mathrm{h}^{2}\right)$ 程度だったのに対して, 本研究 では $q_{b} \cdot V=4000 \sim 17000\left(\mathrm{~m}^{3} / \mathrm{h}^{2}\right)$ で定義され，互いに補 完し合う関係である. 従って, 一概にどちらが適切 な侵食速度式であるとは言えない。

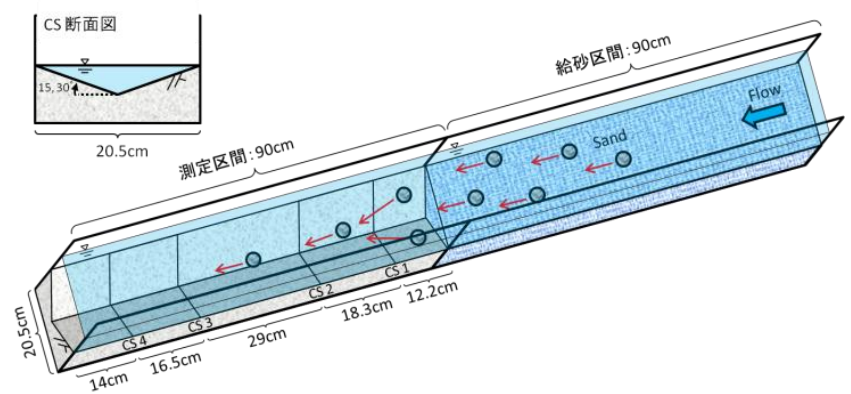

図-5 直線水路鳥瞰図

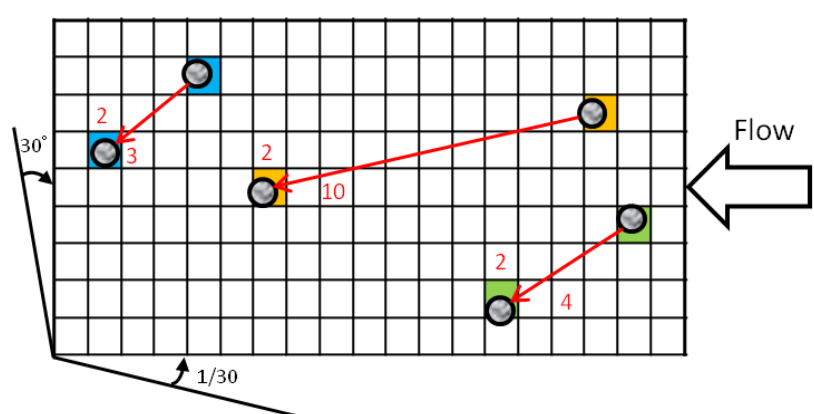

図-6 流砂量の縱横断比を測定する方法の模式図

\section{3. 流砂運動と侵食量に関する実験}

\section{1 実験概要}

\section{a）侵食量}

岩盤上を流れる流砂量の, 縦断方向と横断方向と の割合を調べるために，図-5のような水路を作成し た. 河床は横断方向にも, 水路両岸から水路中央に 向かって $30^{\circ}$ の勾配が設けてあり, 水路中央が一番 低くなっている。一方，水路縦断勾配は $1 / 30$ となっ ている。また，河床は石狩川上流部を想定した石膏 $\left(G_{I}=80.7 \%\right)$ となっており, 流砂量の縦横断比を測定 すると同時に，河床の洗掘量も測定できるように

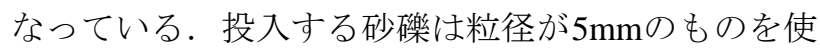
用した。図-5の上流部には給砂地点として，均一に 砂碟が流れるように平坦床を用意している。給砂の 際は，堆積が生じない範囲でできるだけ多くの砂礫 が流れるように, 絶え間無く同じ量を供給し続ける ように注意した。また，その際の砂の供給時間と供 給量を測定して，流砂量を算出している.

\section{b) 流砂運動}

砂礫が図-5の石膏区間に差し掛かると，横断勾配 の影響で水路中央に集約し始める。流下中の砂硯は, 水路中央を除いてはほぼ一様な角度で流れることが 観察された。一方，一度水路中央に集約した砂碩は， 一貫して水路中央を流下寸る傾向にあった.

そこで，まずこれらの様子を水路上方から撮影し， 粒子とほぼ同じ大きさの正方形のグリッドによって 河床を縦断方向及び横断方向に区切り，砂碟を無作 為に抽出した。次にその粒子が縦横それぞれ何マス ずつ進んだか合計してゆく作業を，図-6の要領で繰 り返すことによって，粒子が水路流下方向に対して 何度の方向に転がりやすいか，すなわち流砂量の縦 横断比はどのような割合になっているのかを調べた. 


\section{2 実験結果と考察}

この結果を各case, 測線毎の物理量と併せて表-2 にまとめた。表-2中で黄塗りになっている caseでは, 十分な水深が確保されていないことを意味する。こ の場合流路が三角形断面になっているため, 有効な 水路幅を再定義する必要があり, それに伴って流速 $V$ ，流砂量 $q_{b}$ ，侵食速度 $D$ をそれぞれ補正している.

ここで，図-7として各case後の河床断面図を測線 毎に示す. 図中の測線aでは水路断面全体で均一に 洗掘される傾向にあるが, 測線b,c,dでは下流の測線 になるほど，次第に流砂が水路中央に集中寸る影響 で中央の洗掘が卓越し, 両岸付近では流砂が存在せ ず洗掘も起こりにくくなっているのが見て取れる.

次に，各測点で計測した洗掘深を，それぞれの caseの最大洗掘深で除すことで無次元化し， case毎 に図-8に示す。流量の多いcase4-1では，砂碩は水流 から受ける抗力の影響が卓越するのでcase4-2,3より も縦断方向に流されや寸く，他のcase と同様に下流 の測線ほど幾分か流砂の集中度合が大きくなってい るが, 水路全体としての流砂の集中度合は他のcase より低い。一方, 流量が少ないcase4-2,3では, 砂礫 は重力の影響が卓越するので, 横断方向に流されや すく, 流砂の集中も著しくなっており，表-2の流砂 の移動角度からもそれが分かる。

このことは, 横断方向掃流砂量の縦断方向掃流砂 量に対する比を表す長谷川式(5)でも確かめることが できる.

$$
\frac{q_{b_{y}}}{q_{b_{x}}}=\frac{v_{b}}{u_{b}}+\sqrt{\frac{\tau^{*}{ }_{c}}{\mu_{s} \mu_{k} \tau^{*}}} \tan \omega
$$

ここに $q_{b_{\mathrm{x}}}, q_{b_{y}}$ : 縦断方向及び横断方向掃流砂量, $u_{b}, v_{b}$ : 底面付近の縦断方向及び横断方向流速, $\mu_{s}, \mu_{k}$ : 最大静止及び動摩擦係数, $\tau^{*}{ }_{c}, \tau^{*}$ : 限界無次元掃流力, 限界掃流力， $\omega$ :横断勾配である。流量が増加すれば $\tau^{*}$ も増加し, 式(5)の值は小さくなる. すなわち $q_{b_{x}}$ に対して $q_{b_{y}}$ が小さくなるので, 流砂に対する勾配 の影響は小さくなり，流砂の集中も相対的に小さく なる。逆に流量が減少すればでも減少し, 式(5)の值 は大きくなる．すなわち $q_{b_{\mathrm{x}}}$ に対して $q_{b_{y}}$ が大きくな るので，流砂に対する勾配の影響は大きくなり，流 砂の集中も相対的に大きくなる.

なお，実験中の水面が僅かに振動して石膏河床上 で水の満ち干きが起こることによって，実際は水に よる石亳の洗掘も生じているが，図-8中case4-2,3で 両岸の值が0になっている箇所があるのは, 有効幅 を定義したことにより, 砂磼による洗掘は起きてい ないとして，切り捨てて考えているからである.

また，水路測定区間の上流には平坦床で給砂区間 を設けていることは前述の通りであるが，それらの 境界は段落ちになっている. 流量が少なくなればそ の影響が卓越し水面が振動することで， case4-3など では下流側に位置する測線cであっても局所洗掘が 起こっていないと考えられる. 表-2＼cjkstart直線水路実験の全条件とその結果

\begin{tabular}{|c|c|c|c|c|c|c|c|c|c|c|c|c|}
\hline & \multicolumn{4}{|c|}{ case 4-1 } & \multirow{2}{*}{\multicolumn{4}{|c|}{$\begin{array}{c}\text { case4-2 } \\
0.45\end{array}$}} & \multicolumn{4}{|c|}{ case4-3 } \\
\hline 実験時間(h) & \multicolumn{4}{|c|}{0.30} & & & & & \multirow{2}{*}{\multicolumn{4}{|c|}{2}} \\
\hline 流量(1/s) & \multirow{2}{*}{\multicolumn{4}{|c|}{0.113}} & \multicolumn{4}{|c|}{6} & & & & \\
\hline 投入砂量(kg/s) & & & & & \multicolumn{4}{|c|}{0.072} & \multicolumn{4}{|c|}{0.016} \\
\hline 流砂の移動角度 $0^{\circ}$ & \multicolumn{4}{|c|}{13} & \multicolumn{4}{|c|}{16} & \multicolumn{4}{|c|}{21} \\
\hline 测線 & CS 1 & CS 2 & $\operatorname{cs} 3$ & $\operatorname{cs} 4$ & CS 1 & CS 2 & $\operatorname{cs} 3$ & $\operatorname{cs} 4$ & CS 1 & CS 2 & $\operatorname{cs} 3$ & CS 4 \\
\hline 水深(cn & 6.19 & 7.05 & 6.08 & 6.69 & 4.70 & 6.51 & 5.06 & 5.90 & 3.21 & 3.47 & 3.97 & 4.02 \\
\hline 有効水 & 0.205 & 0.205 & 0.205 & 0.205 & 0.163 & 0.205 & 0.175 & 0.205 & 0.111 & 0.120 & 0.138 & 0.139 \\
\hline 流速 $V(m)$ & 1.50 & 1.18 & 1.55 & 1.30 & 1.57 & 0.82 & 1.35 & 0.99 & 1.12 & 0.96 & 0.73 & 0.71 \\
\hline 流砂量 $q_{b}\left(\mathrm{~m}^{2} / \mathrm{h}\right)$ & 0.75 & 0.75 & 0.75 & 0.75 & 0.60 & 0.48 & 0.56 & 0.48 & 0.20 & 0.19 & 0.16 & 0.16 \\
\hline 洗掘速度 $D(\mathrm{~mm} / \mathrm{h})$ & 79.3 & 65.8 & 66.8 & 46.4 & 59.1 & 40.7 & 31.2 & 27.5 & 9.7 & 9.3 & 6.0 & 8.9 \\
\hline
\end{tabular}
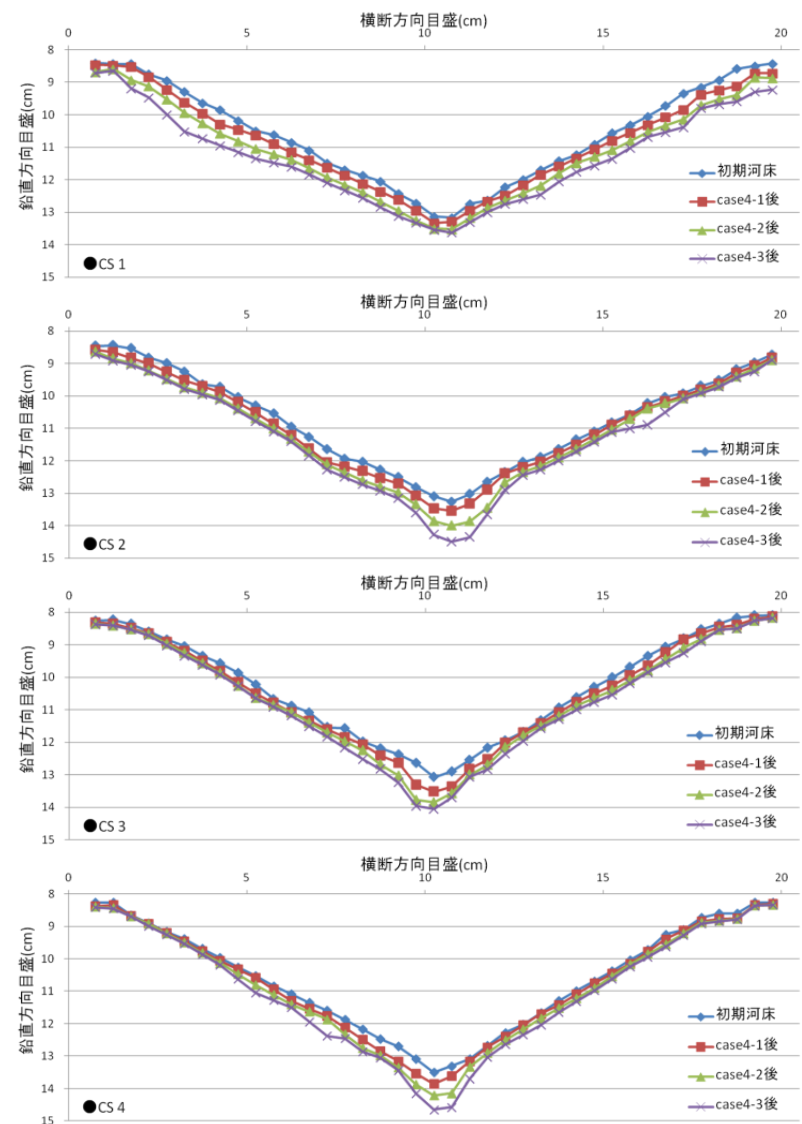

図-7＼cjkstart各測線における各case後の河床断面図

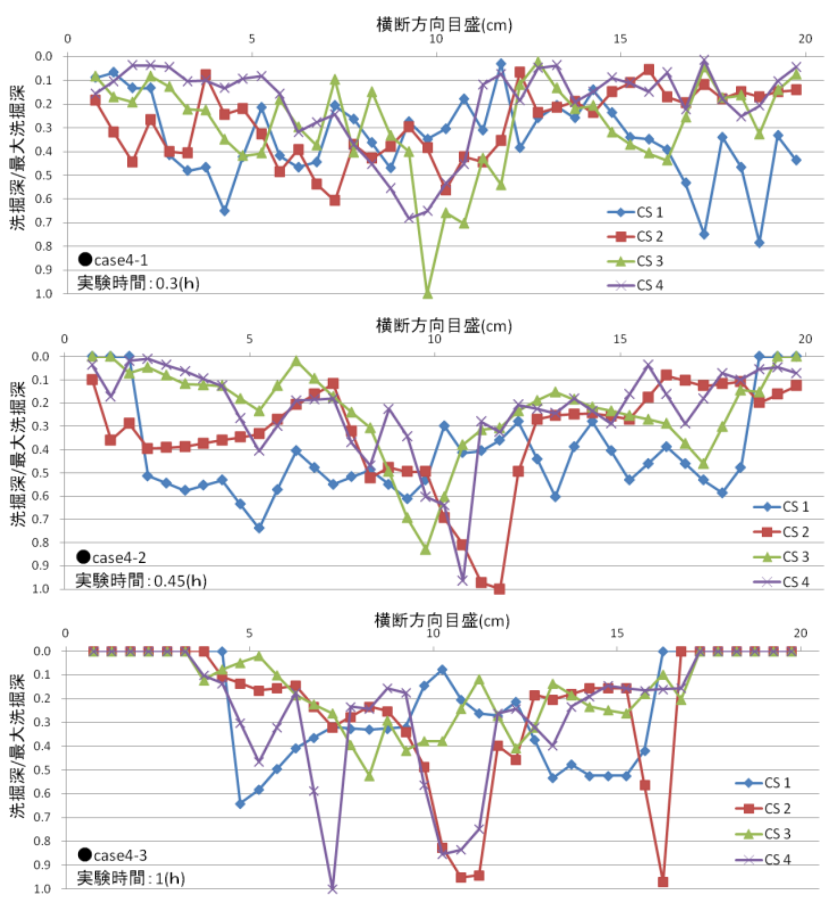

図-8＼cjkstart実験case毎の各測線無次元化河床変動図 


\section{4. 計算モデルによる岩盤侵食モデルの検討}

\section{1 数値計算概要}

直線水路における実験から, 岩盤上の掃流砂の集 中により岩盤が侵食される様子が確認され, 流砂の 集中度合は流れの強さと河床勾配のバランスに影響 されることが示唆された。ここでは本実験結果を基 に，及川ら ${ }^{1)}$ にり提案されている岩盤河床を含む 平面二次元河床変動モデルの流砂モデルに関する検 討を行う。

ここで用いる計算モデルでは, 岩盤上の掃流砂運 動を主流方向は平衡流砂量式である芦田・道上式 ${ }^{5)}$, 横断方向は流砂への横断方向の勾配の影響を考慮し た長谷川の式により表現している。これらの流砂モ デルは河川の河床変動解析では一般的なスキームで あり, 砂州の移動や湾曲部の河床変動などの現象を 再現できることが既往の研究6)で示されている. 著 者らはこれらを岩盤河床上の流砂モデルとして拡張 することで，流砂集中に伴う岩盤の洗堀を表現でき ることを示した。しかしこの流砂モデルは砂砂河床 を対象として導出されているため, 岩盤河床上の流 砂運動を適切に再現できるかは不明瞭である。ここ では，実験と同様の数值実験を行い，実験で得られ た侵食パターンをこの計算モデルでどの程度把握可 能かについての検討を行う。モデルの詳細ついては 及川ら ${ }^{1)}$ の論文を参照されたい。

掃流砂の移動方向は, 河床近傍の流速ベクトルと 河床勾配に大きく影響を受ける．本計算モデルでは これらの影響を前述の長谷川式(5)により考慮してい るが，ここでは流速ベクトルの影響については議論 せず，横断勾配の影響について検討する．横断勾配 の影響度合については，横断勾配 $\omega$ を一定とすれば, 土粒子と河床の摩擦係数 $\mu_{s}, \mu_{k}$, 限界掃流力 $\tau^{*}{ }_{c}$ 及び 掃流力 $\tau^{*}$ に依存する。特に岩盤河床上では，岩盤一 砂粒子の摩擦が砂碅河床上とは異なることが予想さ れ, $\tau^{*}{ }_{c}$ も砂碩河床の場合と異なることが井上ら ${ }^{2)}$ に よって提唱されている。 そこで, 本実験のcase4-1を 対象として計算を行い, 同様の断面での比較を行う。

なお，岩盤河床上に掃流可能な流砂量は砂碩河川 の平衡流砂量より多いことが知られているが，本モ デルはその影響を考慮することができず，過大な流 砂の集中は䃋の堆積を引き起こし, 純粋に河床洗堀 の影響を検討できない。そのため給砂量については 堆積が生じないように実験よりも少なめとしている.

\section{2 数值計算結果と考察}

\section{a）物理的な条件を仮定した場合}

最初に, 河床と粒子の摩擦を表す係数を一般の河 床変動計算と同様の $\mu_{\mathrm{s}} \mu_{\mathrm{k}}=0.5$ とし, 限界掃流力を岩 垣の式から算出したものをRUN1とする. 図-9から 分かるように, 洗堀量の集中が実験よりも上流断面 で起きており，実験で測定された最上流断面以外で は同様の侵食量を示している。これは流砂の集中を 過大評価していることを意味している，なお，流砂
が集中しない箇所においても毎時刻洗掘が起きてい る. これは侵食速度式の切片が水流による洗掘の意 味合いを持った項であり，計算時間を長くとるほど 流砂量に関わらずその効果が結果に反映されたため である. 次に, 岩盤河床一砂粒子の摩擦を大きくと $り \mu_{s} \mu_{\mathrm{k}}=1$ とし, 同様の計算を試みたものをRUN2とす る. 図-9より,流砂の集中が幾分緩和されている様 子が分かる. 同様に, RUN3では長谷川式重力項に影 響のある限界掃流力 $\tau^{*}{ }^{*}$ を 3 割減じることで, 岩盤上 における限界掃流力を低下させる効果を考慮した。 図-9より,流砂の集中具合は幾分弱まるが，河床の 摩擦係数を変更した方が効果が幾分大きいことが分 かる. 最後に,これらの影響を同時に加えたものを RUN4とする。図-9より, 上流側の断面で水路中央部 以外の侵食量がほかのケースより大きくなっており, 幾分実験ケースに近づいている。またいずれのRUN でも流砂の移動角度は表-2の $13^{\circ}$ より大きくなった。

数值計算では河床に接する砂碩に対して, 重力の 効果，言い換えれば横断勾配の影響が利き過ぎてお り，いずれも実験值よりも流砂が一極集中する傾向 が強く表れ，計算結果河床断面(図-9)よりその傾向 が窺えた。このように，横断方向の流砂量の見積 もりが岩盤河床の洗堀に影響を及ぼすことが示唆さ れ, これらの影響, 寸なわち岩盤河床上の流砂運動 を適切に表現することで，モデル精度の向上が期待 できる，本研究では，重力項を調節することで一定 の効果を上げたが，岩盤河床上の流砂運動をより一 般的な形で定式化することが，岩盤河床の河床変動 計算モデルを構築する上で重要であるといえる.
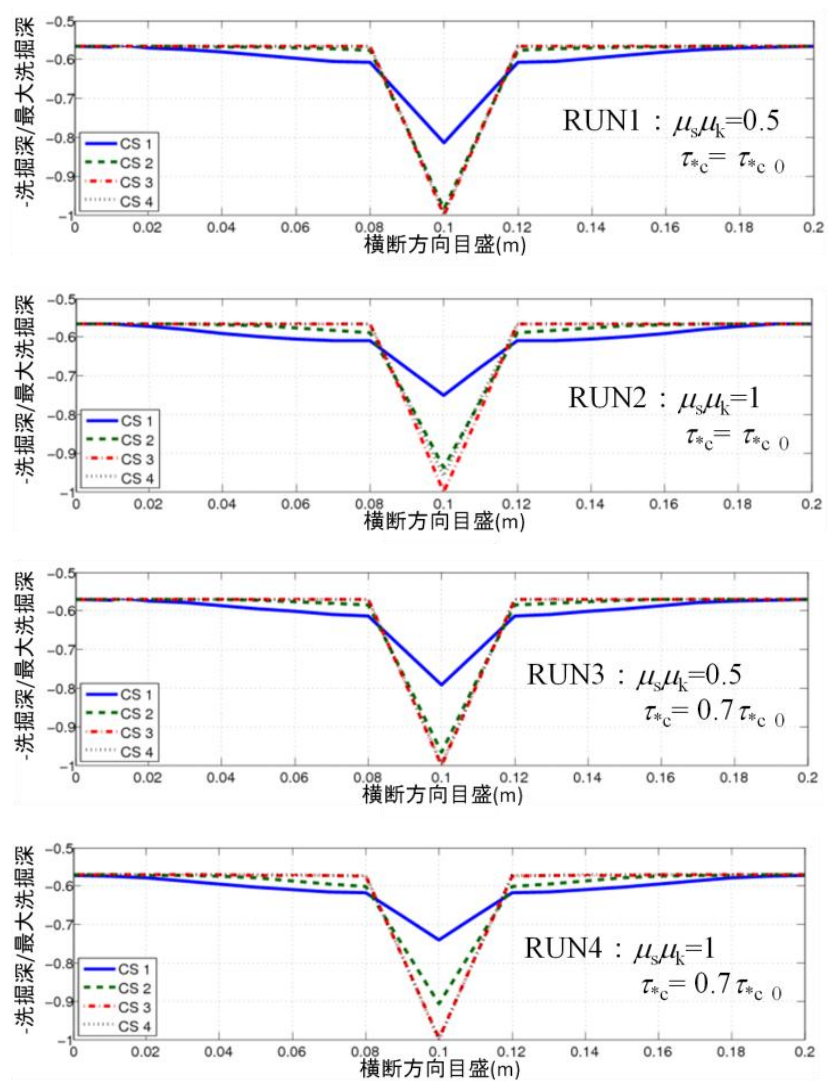

図-9 数值計算RUN毎の各測線無次元化河床変動図a) 

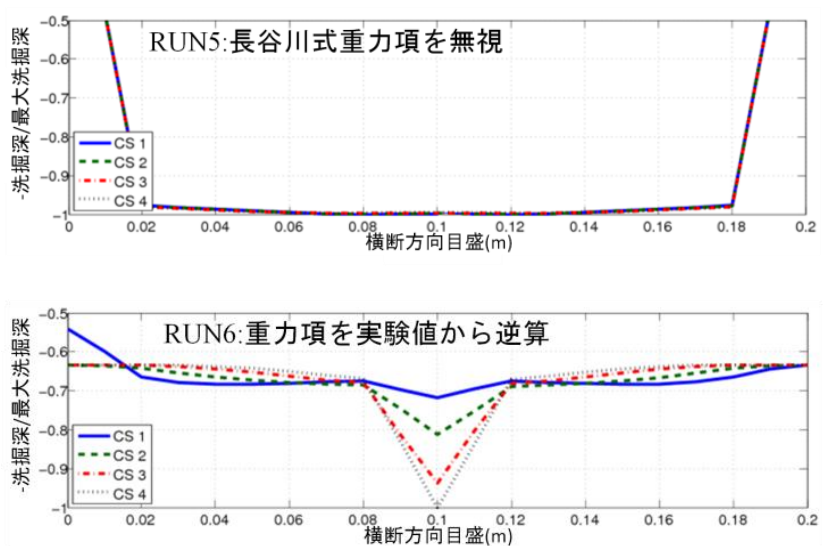

図-10 数值計算RUN毎の各測線無次元化河床変動図 $b$ )

\section{b）実験から計算条件を逆算した場合}

流砂の集中度の観点で，使用したモデルがどの程 度物理現象を再現するのか，a）に対して物理的な有 意性とは無関係に，仮想的に極端な条件を仮定して 計算を行った。

長谷川式重力項を無視することで，流砂が横断勾 配から受ける影響は無いものとし，底面流速から受 ける影響によってのみ移動するような条件をRUN5 とする。図-10より，このとき流砂量は局所的に集 中すること無く分布し, 澪筋は発達せず, 次第に拡 幅していった。

次に，前述の長谷川式(5)を用いて実験結果から作 為的に係数を決定する. 第 4 章の表-2中case4-1から, このとき流砂の移動角度は水路流下方向に対して $13^{\circ}$ であるので流砂量縦横断比は $q_{b_{y}} / q_{b_{x}}=\tan 13^{\circ}$ であり，限界掃流力は数值計算結果の最大值を用い $\tau \tau^{*}=0.3$ とし, 横断勾配は一様に $\omega=30^{\circ}$ とする. いま， $v_{b} \ll u_{b}$ より式(5)の第一項を無視すれば,

$\sqrt{\frac{\tau^{*}{ }_{c}}{\mu_{s} \mu_{k}}}=\frac{q_{b_{y}} / q_{b_{x}}}{\tan \omega} \sqrt{\tau^{*}}=\frac{\tan 13^{\circ}}{\tan 30^{\circ}} \sqrt{0.3} \fallingdotseq 0.219$

となる。(6)を満たすように $\tau^{*}{ }_{c}$ 及び $\mu_{s} \mu_{k}$ を決定した ものをRUN6とする。図-10から分かるように，

RUN1,2,3,4よりも流砂の集中する度合が抑制され， 澪筋の掘れ具合や拡幅も他のRUNと比較して実験結 果を良く再現していることが分かる.

b)のような手法は他の条件における適応性につい ては今後の課題ではあるが，少なくとも本計算ケー スでは，実験による流砂の横断方向と縦断方向の比 をとり，長谷川式の定数部を便宜的に逆算する方法 で，重力項の影響を一番適切に調整し流砂の集中度 合を表現することができた。従って，横断勾配の流 砂運動への影響を実験条件と合わせることができれ ば，本計算モデルで流砂集中による岩盤侵食過程を 再現できる可能性があると言える。つまり，掃流砂 量の縦断方向と横断方向の比がどのような要因で決 定されるのか，実験によってのみならず理論的にも 定式化できれば, 数值シミュレーションの際に汎用 的に用いることが可能となるので，今後更なる解析 が必要である。

\section{5. 結論}

本研究で得られた成果を整理し以下に列挙する.

1）回転水槽を用いて，侵食速度式の粒径依存性及 び岩盤強度依存性を示した。

2）直線水路を用いて，掃流砂量の縦横断比を調べ, 掃流力 $\tau^{*}$ が流砂の集中具合に寄与する影響を考 察した.

3)一般的な河床変動計算を用いて, 従来のモデル では岩盤上の流砂運動が再現しきれず，流砂の 過剩な集中を示した.

4) 2)と 3)を組み合わせることで, 岩盤上の流砂運 動を再現できる可能性を提唱した.

\section{参考文献}

1) 及川森, 岩崎理樹, 山口里実, 清水康行, 木村一郎 : 流 砂の摩耗作用による岩盤侵食に関する実験的検討と数 值シミュレーション, 水工学論文集, 第 55 巻, pp.751756, 2011.

2) Inoue, T., N. Izumi, Y. Shimizu and M. Hamaki : A riverbed evolution calculation method that considers variation in riverbed erosion of soft rock, Proceedings of 7th International symposium on River, Coastal and Estuarine Morphodynamics, RCEM2011, pp.1902-1916, 2011.

3) 竹林洋史, 中元達也, 藤田正治 : 粘着性 - 非粘着性河 床材料混在場における土砂輸送特性一トンレサップ川 を対象として一, 京都大学防災研究所年報, 第 52 号 B, pp.637-645, 2009.

4) 井上卓也, 渡邊康玄, 齋藤大作, 根本深, 松本勝治, 江 崎國夫, 濱木道大 : 軟岩の洗掘を考慮した河床変動計 算手法の開発，河川技術論文集，第 15 巻, pp.321-326 2009.

5) 芦田和男, 道上正規 : 移動床流れの抵抗と掃流砂量に 関寸る基礎的研究, 土木学会論文報告集, 第 208 号, pp.59-69, 1972.

6) 清水康行, 藤田睦博, 平野道夫 : 連続床止め工を有す る複断面河道における流れと河床変動の計算, 水工学 論文集, 第 43 巻, pp.683-688, 1999.

7) Egashira, S. and Ashida, K. United view of the mechanics of debris flow and bed-load, Advances in Micromechanics of Granular Materials, (Edited by H.H.Shen et al.) Elsevier, pp.391-400, 1992.

(2011.9.30 受付) 